\title{
Pelembagaan Hukum Islam Untuk Masa Depan Bangsa Indonesia yang Pluralistik
}

\author{
Ni'matul Huda \\ Universitas Islam Indonesia Yogyakarta
}

\begin{abstract}
Choosing either formalism or cultural models in the institutionalization of Islamic Law in the context of the United State of Republic of Indonesia has not been too easy, and this has even frequently been harsh discourses between both proponents. Therefore, the proponents should first of all seek their common view on the concept, process, and legal and political consequence of such institutionalization. The institutionalization of Islamic Law should not only seek legal-its values for the development, order, security and welfare of the people and state.
\end{abstract}

Keywords: Cultural, formal, institutionalization, Islamic Law, model.

G elombang demokratisasi yang melanda Indonesia pada tahun 1998 ditandai dengan lengsernya Pemerintahan Orde Baru melalui gerakan reformasi, telah memberikan angin segar bagi perkembangan politik, hukum, ekonomi, sosial dan budaya ke arah yang lebih demokratis. Seolah dengan reformasi kita menemukan kemerdekaan dan kebebasan yang selama berpuluh-puluh tahun menjadi obsesi kolektif bangsa Indonesia, akibat politik rezim Orde Baru yang represif.

Isu demokratisasi merupakan sesuatu yang strategis dan fungsional untuk menjawab persoalan bangsa. Demokratisasi merupakan harapan bagi mereka yang menolak penggunaan negara untuk kepentingan agama, sekaligus memberikan tempat untuk agama. Menurut Abdurrahman Wahid (Gus Dur), mekanisme politik yang demokratis dengan sendirinya akan memberikan keuntungan bagi umat Islam yang dalam realitasnya memang mayoritas. Sebagai mayoritas posisinya akan lebih menentukan dalam memberi arah

perjuangan bangsa ini. Sebab, mekanisme politik yang demokratis dengan sendirinya akan menempatkan masing-masing kelompok politik secara proporsional. Di samping itu mekanisme yang rasional dan sehat (demokratis), tentu akan lebih legitimate,-termasuk upaya untuk memformalkan ajaran Islam-, dibandingkan bila diperoleh melalui jalur kekuasaan formal (Ghofur, 2002).

Isu demokratisasi juga memberikan imbas positif kepada Daerah melalui desentralisasi atau otonomi daerah. Dengan otonomi, Daerah diberi keleluasaan untuk mengatur dirinya sesuai aspirasi dan kemampuan yang ada di tiap-tiap daerah. UU No. 22 Tahun 1999 yang kemudian diganti dengan UU No. 32 Tahun 2004 tentang Pemerintahan Daerah telah melimpahkan sejumlah urusan ke Daerah kecuali urusan peradilan, pertahanan keamanan, hubungan luar negeri, moneter dan fiskal, dan urusan agama (Mahfud, 2006). Bagi Daerah yang sudah memiliki kemampuan untuk mengatur urusan yang sudah dilimpahkan boleh 
UNISIA, Vol. XXX No. 65 September 2007

mengaturnya dalam bentuk Peraturan Daerah (Perda).

Peluang keterbukaan tersebut ditangkap oleh masyarakat secara beragam, ada sebagian masyarakat yang ramai-ramai mendirikan partai Islam, sebagai contoh antara lain: Partai Persatuan Pembangunan, Partai Bulan Bintang, Partai Keadilan, Partai Nahdlatul Ulama, Partai Kebangkitan Umat atau pun partai nasional yang berbasis Islam yang ikut Pemilu tahun 1999. Sebagian lain, menuntut segera diberlakukannya Hukum Islam di Indonesia oleh berbagai ormas Islam (Front Pembela Islam, Majelis Mujahidin Indonesia), ada yang menuntut berdirinya Negara Islam di Indonesia (misalnya, Hisbut Tahrir). Dan belakangan muncul Komite Persiapan Penegakan Syariat Islam (KPPSI) di Sulawesi Selatan, yang menuntut penegakan syariat Islam di tingkat Kabupaten/Kota melalui Perda (Tempo, Mei 2006).

Tuntutan pemberlakuan syariat Islam itu muncul karena selama ini berbagai upaya telah dilakukan oleh masyarakat (muslim) supaya hukum Islam mendapat tempat secara wajar di Indonesia - yang notabene mayoritas penduduknya beragama Islam,tetapi hasilnya belum menggembirakan .

Selama Orde Baru, pelembagaan hukum Islam hanya sebatas pada persoalan hukum keluarga, hal ini dapat kita lihat dengan lahirnya UU No. 1 Tahun 1974 tentang Perkawinan, Peraturan Pemerintah No. 28 Tahun 1977 tentang Perwakafan (UU No.41, 2004), UU No. 7 Tahun 1989 tentang Peradilan Agama dan Instruksi Presiden No. 1 Tahun 1991 tentang Kompilasi Hukum Islam (KHI). Kemudian pada masa pemerintahan transisi di bawah Presiden B.J. Habibie, pada tahun 1999, arah dan kebijakan hukum nasional sebagaimana digariskan dalam Garis-garis Besar Haluan
Negara (GBHN) telah mengalami perubahan yang fundamental sebagai produk era reformasi. Dalam arah kebijakan GBHN 1999 (Bab IV.A.2.) disebutkan, antara lain (Ni'matul, 2005)

"...Menata sistem hukum nasional yang menyeluruh dan terpadu dengan mengakui dan menghormati hukum agama dan hukum adat serta memperbaharui perundang-undangan warisan kolonial dan hukum nasional yang diskriminatif, termasuk ketidakadilan gender dan ketidaksesuaiannya dengan tuntutan reformasi melalui program legislasi."

Kemudian di tahun 2000 Pemerintah mengeluarkan UU No. 25 tahun 2000 tentang Program Pembangunan Nasional (Propenas) tahun 2000-2004, dalam Penjelasan Umum Bab III, Pembangunan Hukum, menegaskan:

"Penegakan supremasi hukum berdasarkan nilai-nilai kebenaran dan keadilan serta penghormatan terhadap hak-hak asasi manusia secara universal mengalami degradasi. Kondisi tersebut antara lain disebabkan oleh pemerintahan pada masa lalu tidak mencerminkan aspirasi masyarakat dan kebutuhan pembangunan yang bersendikan hukum agama dan hukum adat... dalam pembangunan hukum. Upaya yang akan dilakukan adalah dengan menyusun dan membentuk peraturan perundang-undangan yang aspiratif dengan mengakui dan menghormati hukum agama dan adat melalui peningkatan peran Prolegnas..." Dari ungkapan tersebut dapat dipahami bahwa pembangunan hukum nasional secara garis besar bersumber pada (a) hukum adat, (b) hukum agama, dan (c) hukum dari luar (Barat). Pada tahun yang sama (1999), Pemerintah juga telah 
Pelembagaan Hukum Islam Untuk Masa Depan Bangsa Indonesia..., Ni'matul Huda

melahirkan dua undang-undang yang berkaitan dengan kepentingan umat Islam, yaitu (1) UU No. 17 Tahun 1999 tentang Penyelenggaraan Ibadah Haji, (2) UU No. 39 Tahun 1999 tentang Pengelolaan Zakat. Kehadiran kedua produk perundangundangan ini secara legal formal tidak membuat posisi hukum Islam bergeser jauh dari posisi semula, yaitu sebagai hukum yang mengatur masalah hukum keluarga.

Selama masa pemerintahan Orde Baru, Pemerintah tidak secara tegas memberikan tempat bagi hukum Islam dalam sistem hukum nasional. Tetapi sekarang, di era reformasi yang sangat mengedepankan demokratisasi, keterlibatan masyarakat dalam pengambilan keputusan untuk urusan publik, kebebasan masyarakat mengadopsi nilai-nilai untuk kehidupan masa depannya, termasuk di sini kompetisi bebas dalam percaturan nilai yang kemudian menjadi tatanan masyarakat atau bahkan sumber hukum, menjadi suatu keharusan yang tidak terelakkan lagi. Sebagai contoh, aspirasi masyarakat di Aceh menghendaki pemberlakuan syariat Islam di Daerah Istimewa Aceh. Begitu kuatnya tuntutan itu akhirnya melalui UU No. 44 Tahun 1999 jo UU No. 18 Tahun 2001 jo UU No. 11 Tahun 2006, pemerintah telah memberlakukan syariat Islam di Propinsi NAD. Pemberlakuan syariat Islam di NAD ternyata menjadi titik awal bagi sebagian daerah lainnya untuk terus mendorong umat Islam mendesak Pemerintah Daerah dan DPRD-nya supaya menerapkan syariat Islam di daerahnya melalui pembuatan berbagai "Perda yang berbasis Syariat", misalnya, Cianjur, Tasikmalaya dan Garut, tetapi juga tidak sedikit yang khawatir dengan formalisasi hukum Islam (Laporan, 2003).

Penelitian terhadap berbagai gerakan yang menuntut pemberlakuan syariat Islam di Indonesia memperlihatkan adanya asumsi bahwa reformasi masyarakat Islam atau islamisasi dapat berlangsung dengan hukum, institusi dan instrumen negara. Demikian pula, penerapan syariat dipandang sebagai obat mujarab untuk mengatasi segala macam problem yang dihadapi daerah - seperti kriminalitas dan prostitusi - ataupun yang dihadapi bangsa Indonesia.

Tetapi, sebagaimana terjadi dalam arena politik pada masa Majelis Konstituante dan di era reformasi, isu penerapan syariat yang digulirkan pemberlakuannya di sejumlah daerah di Indonesia telah memicu kontroversi sengit. Selain pemerintah sendiri, NU, Muhammadiyah, dan berbagai lembaga swadaya masyarakat (LSM) melakukan penentangan yang keras terhadap isu tersebut.

Fenomena pengundangan berbagai peraturan daerah berbasis syariat Islam di sejumlah daerah di Indonesia, selain Aceh, mendapat reaksi yang keras dari Departemen Dalam Negeri. Direktur Jenderal Otonomi Daerah (ketika itu Oentarto), misalnya, mengemukakan bahwa pemerintah pusat akan membatalkan perdaperda syariat, karena bertentangan dengan peraturan yang lebih tinggi. Demikian pula dengan Menteri Dalam Negeri Hari Sabarno (ketika itu), sehubungan dengan Perda yang mengatur pemberlakuan syariat Islam di Pamekasan, Madura, menurutnya, Perda tersebut harus dicabut oleh pemerintah daerah dan DPRD setempat, karena bertentangan dengan UU No. 22 Tahun 1999 tentang Pemerintahan Daerah (Suara Pembaruan, Nopember 2002).

Ketika ramai-ramai isu pencantuman tujuh kata Piagam Jakarta dalam amandemen UUD 1945, NU dan Muhammadiyah - dua organisasi Islam terbesar di Indonesia - menyikapinya dengan menolak pencantuman ke tujuh kata itu dalam Pasal 29 UUD 1945. Sikap NU dan 
UNISIA, Vol. XXX No. 65 September 2007

Muhammadiyah ini dikeluarkan dalam sebuah konperensi pers bersama antara Ketua Umum PB NU, K.H. Hasyim Muzadi, dan Ketua PP Muhammadiyah, Ahmad Syafii Maarif, pada 7 Agustus 2002. Penolakan ini didasarkan pada pandangan bahwa formalisasi agama harus didukung budaya dan kesadaran beragama, bukan semata tertulis dalam konstitusi. Isu penerapan syariat Islam juga menuai reaksi dari berbagai LSM. Salah satu LSM yang paling sistematis melakukan counter wacana terhadap isu penerapan syariat Islam di Indonesia adalah Jaringan Islam Liberal (JIL).

Ironisnya, sikap PB NU dan PP Muhammadiyah hanya menerawang di tingkat pusat dan elit kedua organisasi tersebut. Di daerah-daerah di mana isu penerapan syariat menyeruak, seperti di Aceh dan Sulawesi Selatan, kebanyakan anggota NU dan Muhammadiyah merupakan eksponen-eksponen yang mendukung secara gigih pemberlakuan syariat Islam (Taufik, 2004).

Polemik semacam itu pada masa sebelumnya sudah pernah muncul, antara yang menghendaki secara ketat pemberlakuan syariat Islam (aliran formalistik) dan yang tidak menghendaki formalisasi hukum Islam di Indonesia, tetapi lebih mengarah kepada budaya masyarakat yang Islami (aliran kultural). Polemik serupa juga terjadi pada 13 Juni 2006, dimana sejumlah 56 anggota DPR mengirim surat kepada Ketua DPR Agung Laksono agar segera mengirimkan surat kepada Presiden agar memperbaiki dan mencabut semua perda kabupaten/kota yang bernuansa syariat Islam (Tempo, Mei 2006). Pemberlakuan perda tersebut dinilai melanggar konstitusi dan Pancasila. Namun, pada 27 Juni 2006, 134 anggota DPR lain justru meminta Ketua DPR mengabaikan surat itu. Dan pada 4 Juli 2006, Ketua DPR Agung Laksono menyampaikan hasil Rapat Konsultasi Pimpinan DPR dengan Pimpinan Fraksi mengenai polemik antar anggota DPR mengenai Perda yang bermasalah dinyatakan selesai. Perdebatan lewat surat "petisi" dari 56 anggota DPR maupun "kontrapetisi" yang ditandatangani 134 anggota DPR sama-sama disepakati untuk diakhiri. Jika memang ada masyarakat yang berkeberatan dengan perda tertentu, negara menyediakan saluran hukum untuk meminta pengujian (Kompas, Juli 2006). Melalui tulisan ini ingin dikaji bagaimana kebijakan pelembagaan hukum Islam untuk masa depan bangsa Indonesia yang pluralistik.

\section{Pemikiran Intelektual Muslim di Indonesia}

Dasa warsa 1980 dan 1990-an adalah merupakan zaman baru kebangkitan pemikiran intelektual muslim. Hal ini paling tidak ditandai dengan munculnya beberapa literatur yang mencoba mencermati secara sistematis perkembangan dunia intelektual Muslim Indonesia, terutama kaitannya dengan corak dan visi pemikiran yang mereka kembangkan serta posisi mereka di antara komunitas intelektual yang terus melakukan improvisasi tersebut. Catatan cukup lengkap yang mencoba memotret peta baru pemikiran Islam di Indonesia pada tahun 1980-an, antara lain Fachry Ali dan Bahtiar Effendy dalam Merambah Jalan Baru Islam (Fachry, 1996). Survey mereka menunjukkan munculnya empat corak pemikiran keislaman yang sedang dikembangkan intelektual muslim.

Pertama, "neo-modernisme", yaitu pemikiran keislaman yang menggabungkan dua faktor penting; modernisme dan tradisionalisme. Dalam aliran ini masuk dua 
Pelembagaan Hukum Islam Untuk Masa Depan Bangsa Indonesia..., Ni'matul Huda

sosok intelektual, Nurcholis Madjid dan Abdurrahman Wahid. Kedua, "sosialisme demokrat", yaitu gerakan Islam yang melihat cita-cita keadilan sosial dan demokrasi sebagai unsur pokok Islam. Para penganjurnya M. Dawam Rahardjo, Adi Sasono dan Kuntowijoyo. Ketiga, "universalisme", yaitu gerakan pemikiran Islam yang memandang Islam sebagai ajaran universal. Obsesi pokok corak ini adalah: "bahwa Islam dan seluruh perangkat nilainya bisa dijadikan alternatif dari kemeraosotan nilai-nilai Barat". Para pendukung aliran ketiga ini adalah M. Amin Rais, Jalaluddin Rahmat dan AM. Saefudin. Keempat, "modernisme", yaitu gerakan pemikiran yang melibatkan Islam ke dalam persoalan-persoalan sosial-politik yang lebih luas. Para tokoh penganjur aliran ini adalah Djohan Effendy dan Achmad Syafi'i Ma'arif.

Selanjutnya potret lain yang cukup penting dalam menyoroti perkembangan peta pemikiran umat Islam adalah tulisan dari William Liddle dalam monograf Politics and Cultural in Indonesia. Melalui pendekatan politik, Liddle menemukan tiga corak pemikiran Islam di Indonesia. Pertama, "indegenist", yaitu kelompok pemikiran yang percaya bahwa Islam bersifat universal. Namun dalam prakteknya, Islam tidak dapat dilepaskan dari konteks budaya setempat. Gagasan tentang upaya "pribumisasi Islam", atau "kontekstualisasi doktrin Islam" misalnya, adalah usaha para intelektual Islam untuk mempertemukan Islam dengan konteks budaya setempat. Para pendukung "indegenist" ini adalah Nurcholis Madjid dan Abdurrahman Wahid dan Munawir Sadzali.

Kedua, "sosial reformis' yaitu gerakan Islam yang lebih menitikberatkan pada pemikiran dan aksi guna mengatasi berbagai kemiskinan dan ketimpangan sosial yang masih melanda umat Islam sebagai akibat proses pembangunan yang bersifat top- down. Pemikiran penganut aliran ini senantiasa mencari alternatif yang bias dijadikan model pembangunan yang tepat bagi upaya untuk meningkatkan kesejahteraan rakyat. Kelompok ini diwakili oleh Dawam Rahardjo, Adi Sasono dan Muslim Abdurrahman.

Ketiga, "universalisme", yaitu kelompok pemikiran yang percaya bahwa al-Qur'an dan hadist yang dibawa Nabi Muhammad saw, sudah sangat sempurna dan dapat diterapkan langsung pada masyarakat apapun. Yang dapat digolongkan dalam kelompok ketiga ini adalah M. Amin Rais, Endang Saefuddin Anshary, dan AM. Saefuddin.

Dalam kerangka hubungan antara Islam dan negara di Indonesia selama ini mengalami gelombang pasang surut. Ada yang beranggapan bahwa semakin baik hubungan agama dengan negara, maka semakin besar peluang hukum Islam untuk diterapkan dan sebaliknya. Oleh sebab itu perjalanan politik umat Islam mempunyai keterkaitan dengan perkembangan hukum Islam.

Abdul Aziz Thaba menggambarkan hubungan itu dengan tiga bentuk hubungan, yaitu antagonistik (1966-1981), resiprokal kritis (1981-1985) dan periode akomodatif (1985-1999) (Halim, 2000).

Dalam format hubungan yang bersifat antagonistik, kepentingan politik Islam termasuk kebutuhan hukum masyarakat, tidak terakomodasi dalam kebijakankebijakan rezim Orde Baru. Jika pun ada kebijakan yang menyangkut umat Islam, tetapi yang lahir adalah produk hukum yang bertentangan dengan ajaran Islam. Misalnya, munculnya RUU Perkawinan yang sekuler. Keinginan untuk melakukan unifikasi hukum perkawinan yang seragam untuk semua penduduk, jelas menjadi bukti betapa rezim Orde Baru tidak mempertimbangkan kepentingan umat Islam. 
UNISIA, Vol. XXX No. 65 September 2007

Pada situasi yang antagonistik tersebut, kelompok nasionalis sekuler dan non muslim sangat diuntungkan. Orde Baru lebih yakin menjalin hubungan dengan pihak Angkatan Bersenjata di bidang keamanan, sementara bidang pemerintahan kelompok sekuler dan non muslim memperoleh angin segar kekuasaan. Pihak inilah yang secara terus menerus menghembuskan sikap kecurigaan terhadap Islam dengan mengembangkan isu negara Islam. Mereka khawatir, jika Islam dan negara berhubungan dengan baik, gerak mereka termasuk dalam menjalankan misi agamanya akan terganggu.

Dalam situasi yang demikian, rezim Orde Baru secara ketat membatasi setiap kepentingan politis hukum Islam. Politik Islam Soeharto lebih memilih dan memberi kesempatan dalam Islam ibadah, seperti pembangunan masjid, zakat, dan haji. Sementara aspek muamalah, misalnya mengangkat aspek ajaran hukum Islam menjadi hukum nasional sangat dibatasi kalau bukan ditiadakan.

Sejalan dengan itu, Soeharto lebih menyukai kelompok intelektual Islam yang modernis karena dianggap mendukung kebijakan pembangunan dan modernisasi pembangunan. Kelompok pemikir ini dianggap lebih bersahabat karena tematema pemikiran yang dikembangkan adalah lebih pada nilai moral ajaran, bukan penggalangan politik. Ada relasi antara pemikiran modernisme dan kepentingan politik, sehingga mazhab pemikiran ini lebih leluasa dalam mengekspresikan pikiran mereka selama Orde Baru. Lain halnya dengan kalangan tradisionalis yang mendapat pengawasan ketat dari setiap ide dan wacana yang dikembangkan.

Namun, situasi yang kurang mesra itu bergeser sejalan dengan perkembangan pemikiran Islam masyarakat. Pendekatan legalistic-formal kemudian berangsur-angsur melunak. Akibat perkembangan inilah kemudian menciptakan hubungan yang resiprokal-kritis. Ada keinginan saling memahami posisi. Periode ini diawali dari political test yang dilakukan pemerintah dengan menyodorkan konsep asas tunggal Pancasila bagi organisasi sosial politik dan kemudian menjadi asas organisasi massa yang ada di Indonesia. Dalam konteks hubungan resiprokal kritis, yang menyangkut pembinaan hukum Islam lebih bersifat pengembangan pisik, terutama pengembangan beberapa sarana lembaga keagamaan, belum memasuki pembangunan substansial.

Akibat adanya akomodasi dari umat Islam terhadap asas tunggal, maka momentum ini menciptakan hubungan yang bersifat akomodatif. Akomodasi negara terhadap kepentingan umat Islam tidak terlepas dari semakin kuatnya pengaruh pemikiran baru dari aktivis-aktivis Islam yang telah dimulai akselerasi wacana keislaman di tahun 1970an yang dimotori Nurcholis Madjid. Arah pemikiran intelektualisme Islam ini mendapat respon positif dari penguasa Orde Baru. Sehingga melalui pengembangan pemikiran ini muncul saling kesepahaman antara Islam dan negara. Pada hubungan yang akomodatif inilah kebijakan politik hukum Islam Orde Baru semakin aspiratif, dengan lahirnya UU No. 7 Tahun 1989 tentang Peradilan Agama. Kemudian menyusul Instruksi Presiden No. 1 Tahun 1991 tentang Kompilasi Hukum Islam, dukungan pemerintah terhadap kelahiran Ikatan Cendekiawan Muslim Indonesia (ICMI), pendirian Bank Muamalat Indonesia, keputusan bersama tingkat menteri tentang Bazis dan kebijakan tentang jilbab dan penghapusan Porkas dan SDSB, telah memperjelas kecenderungan rezim Orde Baru untuk mengabulkan keinginan masyarakat Islam. Perkembangan ini 
Pelembagaan Hukum Islam Untuk Masa Depan Bangsa Indonesia..., Ni'matul Huda

tampaknya menjadi titik balik dalam hal hubungan antara Islam dan pemerintah, dimana mereka masing-masing tidak lagi dipandang sebagai musuh, akan tetapi sebagai partner dalam usaha yang dilakukan oleh Orde Baru untuk membangun negara. Wacana tentang pendirian negara Islam tidak lagi mengemuka karena tidak semua masyarakat muslim menyepakatinya. Mereka justru cenderung untuk memfokuskan diri pada pikiran-pikiran di mana nilai-nilai Islam dapat diintegrasikan ke dalam sistem ideologi negara tersebut.

Kalau dicermati lebih jauh bagaimana sikap umat Islam terhadap kebijakan politik Orde Baru, setidaknya terdapat dua paradigma yang berkembang; pertama, paradigma yang menginginkan diwujudkannya ajaran Islam dalam kehidupan berbangsa dan bernegara melalui pranata negara. Dengan ungkapan lain, paradigma ini mencakup pandangan yang menghendaki - istilah Muchtar Mas'oed "islamisasi negara demi islamisasi masyarakat" baik dalam bentuk yang konvensional (konfrontatif-reaksioner) maupun yang lebih sistematis - lazim disebut Islam struktural. Kedua, cara pandangnya lebih terfokus pada pemberdayaan masyarakat, dan umat Islam adalah mayoritas (Mas'oed, 1996).

Strategi perjuangan Islam model pertama yang lebih menekankan strategi konvensional-konfrontatif aatau reaksionis paling tidak sampai akhir 1980-an, hampir semua upaya terpatahkan dan tidak cukup kuat untuk membuat pemegang kekuasaan mengakomodasi aspirasi mereka. Sementara itu, terjadi perubahan sosiologis umat Islam diakhir 1970-an, dengan munculnya generasi muda yang memiliki kemampuan intelektual yang lebih baik, dengan penerapan strategi non-konvensional, yakni akomodatif, tidak konfrontatif.
Sedangkan strategi model yang kedua didukung pula oleh generasi muda yang muncul di era 1970-an dengan konsepnya "sekularisasi". Gerakan ini lazim pula disebut dengan gerakan Islam kultural. Penerapannya ada dua versi; pertama, penekanan pada "strategi kebudayaan" dan kedua, penekanan pada "membangun kapasita politik masyarakat",sehingga tidak heran muncul selogan "Islam Yes, Politik No." Agendanya adalah: 1) menekankan upaya community development untuk memperbaiki kondisi kehidupan umat di tingkat bawah;2) mencari alternatif terhadap peranan pemerintah yang berlebihan; 3 ) memanfaatkan jaringan organisasi nonpemerintah (Mas'oed, 1996).

Perubahan format dan langgam politik Islam seperti strategi yang dilakukan oleh kelompok kultural bukanlah terjadi tanpa alasan dan dasar-dasar empirik yang nyata. Gagasan-gagasan itu lahir karena tuntutan riil yang dihadapi komunitas politik Islam. Demikian menonjolnya gerakan transformasi pemikiran dan praktik politik Islam ini, sehingga sampai tingkat tertentu mampu meredakan ketegangan politik antara Islam dan negara (Bahtiar, 2001).

Studi mendalam yang dilakukan oleh Moh. Mahfud MD. terhadap hubungan kausalitas antara hukum dan politik menjelaskan bahwa keadaan politik tertentu dapat mempengaruhi produk hukum. Hal itu dapat dilihat dalam kasus kelahiran UU No. 1 Tahun 1974 tentang Perkawinan dan UU No. 7 Tahun 1989 tentang Peradilan Agama. Kedua UU tersebut sama-sama lahir pada era Soeharto (Orde Baru), tetapi hubungan politik antara pemerintah dan Umat Islam atau hubungan antara negara dan agama yang melatarbelakangi keduanya berada dalam suasana yang berbeda. UU Perkawinan lahir dalam keadaan politik konflik dan saling curiga, sedangkan UU No. 
UNISIA, Vol. XXX No. 65 September 2007

7 Tahun 1989 lahir ketika hubungan pemerintah dan umat Islam sedang melakukan saling akomodasi (Mas'oed, 1996).

Dari kedua UU yang lahir pada periode hubungan yang berbeda itu kita dapat melihat betapa keadaan politik tertentu telah menentukan pilihan atas materi produk hukum.

\section{Kebijakan "Formalisasi” Hukum Islam dan Pluralisme}

Jika diamati masyarakat Islam Indonesia, khususnya para tokoh muslim yang terlibat dalam pembahasan mengenai perberlakuan hukum Islam di Indonesia, setidaknya ada dua kelompok, yaitu kelompok yang menekankan pada pendekatan normatif (formalisme) dan kelompok yang menekankan pada pendekatan kultural (budaya). Pendekatan ini sebagai perwujudan kehidupan politik dari masing-masing kelompok, atau justru sebaliknya, yakni bahwa cermin politik mereka sebagai wujud keyakinan terhadap jenis pendekatan tersebut. Hal ini juga sekaligus sebagai jawaban dari persoalan bagaimana penerapan hukum Islam, ketika disepakati bahwa hukum Islam merupakan salah satu dari tiga bahan baku dalam pembinaan hukum nasional (Azizi, 2002).

Pertama, pendekatan formal (normatif). Menurut pendapat ini, hukum Islam harus diterapkan kepada mereka yang sudah mengucapkan dua kalimah syahadah atau sudah masuk Islam. Istilah "transfigurasi hukum Islam" tidak akan popular, kecuali berarti bahwa mereka yang beragama Islam harus menjalankan atau dipaksakan untuk menerima hukum Islam dalam kehidupan sehari-hari. Oleh karena itu, proses kehidupan politik, termasuk partai politik, adalah dalam rangka atau sebagai alat untuk menerapkan hukum Islam secara normatif dan formal ini. Konsekuensinya, pelaksanaan Piagam Jakarta menjadi persoalan besar dan serius yang harus selalu diperjuangkan, oleh karena merupakan satu-satunya cara untuk penerapan hukum Islam secara formal -kalau perlu dipaksakan- di negara Indonesia.

Jika ditarik ke atas lagi dari sisi ekstrimitas, pendekatan ini menjadi skriptualis dan tekstualis yang biasanya kurang mempertimbangkan kontekstual dan lingkungan sosiologis. Pada dasarnya pendekatan normatif tidak terlalu jelek jika akan dapat diposisikan sebagai pengontrol. Namun jika berlebihan akan sampai pada skriptualis dan pemaksaan tersebut. Sampai batas ini, upaya transfigurasi tidak merupakan jawaban karena cenderung pada pemaksaan secara formal ideologis. Dan jika pendekatan ini yang diterapkan, persoalan yang muncul, adalah hukum Islam yang mana yang dimaksud?

Pertanyaan ini sangat serius, terutama sekali ketika ditemukan kenyataan terjadinya perbedaan pendapat tentang hukum Islam itu sendiri. Persoalan seperti inilah yang sering terjadi sebagai ekses upaya islamisasi di beberapa negara Timur Tengah yang kemudian hampir tidak pernah selesai. Tampaknya pertanyaan hukum Islam yang mana ini yang akan selalu muncul ke permukaan, seandainya perjuangan menerapkan Piagam Jakarta itu berhasil. Persoalan tersebut bukan masalah kecil, namun dapat menjadi masalah serius, terutama sekali ketika tidak dapat disatukan dalam menerima definisi tentang hukum Islam itu sendiri.

Tipologi "formalistik" menunjukkan suatu mode pemikiran yang mengutamakan peneguhan dan ketaatan yang ketat pada format-format ajaran Islam. Dalam konteks politik, pemikiran formalistik menunjukkan 
Pelembagaan Hukum Islam Untuk Masa Depan Bangsa Indonesia..., Ni'matul Huda

perhatian terhadap suatu orientasi yang cenderung meneropong bentuk-bentuk masyarakat politik Islam yang dibayangkan (imagined Islamic polity).

Kedua, Pendekatan kultural. Menurut pendapat ini yang terpenting bukan formalisme penerapan hukum Islam atau dengan pendekatan normatif ideologis. Namun penyerapan nilai-nilai hukum Islam ke dalam masyarakat itulah yang lebih penting. Gerakan ini dalam tipologi pemikiran substansivistik (Syafi'i, 1995).

Oleh karena adanya heterogenitas masyarakat di Indonesia telah menyebabkan pluralisme dan dualisme hukum menjadi ganjalan bagi reformasi hukum. Masih kuatnya tingkat ketergantungan pada produk hukum warisan kolonial terlihat dari beberapa peraturan perundang-undangan yang masih diambil dari warisan penjajahan Belanda. Konsekuensi dari sikap ini dibuktikan dengan terjadinya pengelompokan hukum; (1) adanya kelompok pembela hukum adat; (2) kelompok pembela hukum Islam; dan (3) kelompok pembela warisan hukum Belanda (Subekti, 1982). Kelompok-kelompok ini sudah ada semenjak Belanda menguasai perundang-undangan Hindia Belanda.

Runtuhnya kekuatan kolonial Belanda tidak secara spontan menghancurkan power of laws-nya. Para pembela kelompok ini mempunyai pengaruh yang kuat dan sering menjadi ganjalan dalam pembaruan hukum di Indonesia. Para pemimpin nasional dan pakar hukum dengan semangat untuk menghancurkan hukum warisan penjajah melakukan berbagai bentuk reformasi hukum untuk menggantikan kebijakan produk kolonial (Sayuti, 1987).

Upaya reformasi hukum ini ternyata tidak semudah yang dibayangkan. Pro dan kontra hukum seringkali sulit dipertemukan.
Menyingkirkan secara total hukum warisan kolonial merupakan pekerjaan yang berat, bagi suatu negara yang majemuk, seperti negara Indonesia. Sistem-sistem hukum yang ada, begitu berat hubungannya dengan kepercayaan agama dan kultur masyarakat, selain itu iklim politik yang kurang mendukung ikut berpengaruh, sehingga unifikasi hukum tidak dapat berjalan efektif.

Transformasi nilai tauhid menjadi hukum Islam yang aplikatif berlangsung melalui sosialisasi dan pelembagaan nilai-nilai Islam yang kemudian diterima oleh masyarakat sebagai nilai-nilai dan hukum Islam sebagai rujukan dalam memecahkan masalah yang mereka hadapi. Pada saat itu secara politis muncul kebutuhan akan pelembagaan hukum Islam, kemudian muncul aspirasi umat Islam dalam bidang pembangunan hukum nasional.

Pelembagaan itu menunjukkan suatu kenyataan bahwa nilai dan fikrah umat Islam dalam bidang hukum dengan kewajiban bertahkim kepada syariat Islam, secara sosiologis dan kultural tidak pernah mati dan selalu hadir dalam kehidupan umat dalam sistem politik mana pun, baik masa kolonialisme Belanda, Jepang, maupun masa kemerdekaan dan pembangunan dewasa ini. Berkat kerja sama antarsemua kekuatan umat dan kejelian pemerintah membaca aspirasi umat Islam dalam rangka pembangunan hukum nasional, maka hukum Islam yang melekat dan hidup pada masyarakat dilembagakan dalam sistem hukum nasional, khususnya yang berkaitan dengan kehidupan keluarga muslim. Hukum yang hidup kemudian menjadi hukum positif (Amrullah, 1996).

Formalisasi dan pemberlakuan syariat Islam dalam konteks Negara Kesatuan Republik Indonesia memang tidak semudah pengucapannya, sebab pada tataran konsep, proses, dan konsekuensi hukum 
maupun politiknya masih harus dicarikan titik persamaan pandang terlebih dahulu. Secara konsepsional, ediom tentang "syariat Islam" masih terus diperdebatkan; apakah mengikuti pola pandang yang inklusif, eksklusif, atau mungkin yang sekuler. Demikian juga proses dan konsekuensi dari formalisasi syariat Islam-pun mengalami pasang dan surut dalam pembaharuan sistem ketatanegaraan Indonesia.

Membahas kedudukan hukum Islam di tengah-tengah hukum nasional dipandang sudah tidak relevan lagi jika yang dimaksudkan hanya untuk mencari legitimasi keberadaan hukum Islam. Era pertentangan antara teori resepsi dengan hukum Islam atau dengan teori receptio in complexu menurut Qodri Azizy sudah selesai. Oleh karena itu, pembahasannya tidak sekadar mencari legitimasi legal formal, namun harus diarahkan pada seberapa banyak hukum Islam mampu menyumbangkan nilai-nilainya dalam rangka kemajuan, keteraturan, ketentraman dan kesejahteraan dalam kehidupan berbangsa dan bernegara (Azizi, 2002).

Memasuki periode reformasi, dengan telah dimasukkannya hukum agama sebagai sumber hukum nasional dalam GBHN 1999, maka kedudukan ketiga sumber hukum yaitu hukum adat, hukum warisan kolonial (Barat) dan hukum Islam adalah sama dan seimbang. Secara teoritis kondisi Indonesia memasuki era demokratisasi. Kalau pada masa Orde Baru Presiden dengan mudah mengeliminir atau bahkan memberangus nilai-nilai hukum Islam dalam sistem hukum nasional kita, kini tidak akan mungkin dapat terjadi seperti itu lagi. Dalam kompetisi yang mencakup eklektisisme itu tampaknya harus selalu melalui koridor demokratis, bukan kekuasaan eksekutif. Artinya, kenyataan mayoritas masyarakat menjadi fakta dan bukti yang dominan dalam perjalanan hukum nasional. Dan dalam konteks ini, usaha dengan cara demokratisasi juga mempunyai kesempatan dan fungsi yang sangat menentukan, oleh karena kepentingan umum harus menjadi acuan dalam pengambilan keputusan untuk publik, termasuk hukum. Ketika kompetisi yang demokratis itu terjadi, maka usaha secara konsepsional menjadi bagian strategi yang tidak dapat diabaikan. Sehingga ketika kita berbicara mengenai menjadikan hukum Islam sebagai sumber hukum nasional, maka diperlukan sistem kerja positivisasi hukum Islam yang dapat diterima secara keilmuan dan dalam proses demokratisasi, bukan indoktrinasi.

Islam sebagai ajaran rahmatan lil 'alamin memiliki peluang yang cukup signifikan untuk menjadi spirit sistem hukum nasional dengan berbagai konsep dan doktrinnya yang universal. Dalam hal ini tidak berarti negara berubah menjadi negara Islam dan hukum yang diberlakukan adalah hukum Islam dalam arti formil. Tetapi yang perlu dibangun adalah sebuah sistem yang direduksi dari berbagai tata nilai keislaman yang tidak sektarian dan eksklusif. Karena kembali pada hakikat Islam adalah ajarannya yang mampu merespon konflik sosial, politik dan segala persoalan kebangsaan yang dihadapi (Murjani, 2002).

Asumsinya adalah jika suatu sistem telah terbangun secara Islami niscaya akan terlahir produk-produk yang islami pula. Artinya nilai-nilai Islam dijadikan sebagai ruh atau spirit yang harus merasuk dalam sistem negara. Negara adalah badan, raga yang mesti membutuhkan ruh agama. Dalam konsep ini, keberadaan negara dengan sistemnya tidak lagi dipandang semata-mata sebagai hasil kontrak sosial dari masyarakat yang bersifat sekular, akan tetapi lebih dari itu, negara dipandang sebagai jasad atau badan yang niscaya dari idealisme ketuhanan. Sedangkan agama 
Pelembagaan Hukum Islam Untuk Masa Depan Bangsa Indonesia..., Ni'matul Huda

adalah substansi untuk menegakkan cita keadilan semesta (Wahid, 1993), sehingga format hukum Islam sebagai ius constituendum adalah hukum nasional yang islami, bukan hukum dalam artian formil berlabel Islam.

Menurut KH. Sahal Mahfudh, terciptanya hukum yang ideal dalam masyarakat madani dengan demikian harus dimulai juga dengan menyerap nilai-nilai hukum universal tersebut di atas dalam kerangka kemasyarakatan yang proporsional (Sahal, 2001). Nilai-nilai hukum universal yang dimaksud itu meliputi: keadilan, kejujuran, kebebasan, persamaan di muka hukum, perlindungan hukum terhadap masyarakat tak seagama, dan menjunjung tinggi supremasi hukum Allah. Maksudnya adalah bahwa nilai tersebut harus diupayakan tertanam dan terimplementasikan dalam segala unsur masyarakat madani, mulai dari system kelembagaan dan unsur pendukungnya. Dengan istilah penyerapan nilai, berarti bahwa prosesnya itu bersifat kultural, bukan pemaksaan secara normatif. Dengan pendekatan secara kultural seperti ini, K.H. Sahal yakin "akan memperkecil kendala yang ada pada tahap implementasi". Oleh karena itu, menurutnya "labelisasi yang sering menimbulkan sikap antipati dan kecurigaan dari kalangan masyarakat juga hendaknya diminimalkan".

Lebih lanjut K.H. Sahal mengatakan, menciptakan masyarakat madani dalam konteks ke-Indonesia dari kacamata hukum Islam, dengan demikian tidak "dengan" atau "tanpa" hukum Islam, namun lebih kepada mempertimbangkan dan menyerap nilai-nilai moral positif yang terkandung dalam hukum Islam itu sendiri. Menerapkan hukum Islam dalam arti formalisasi hukum Islam terkadang belum merupakan solusi terbaik bagi proses formulasi hukum yang ideal bagi sebuah masyarakat madani. Demikian pula eliminasi hukum-hukum yang ada dalam masyarakat, khususnya hukum Islam dalam proses tersebut juga bukan merupakan langkah yang bijaksana, karena bagaimana keberadaannya, baik sebagai sebuah nilai maupun sebagai sebuah peraturan yang berlaku tetap mendapatkan legitimasi yang kuat dalam masyarakat Indonesia. Namun meskipun demikian, ruang gerak bagi proses berkembangnya hukum-hukum yang ada di Indonesia, terutama hukum Islam, harus tetap dibiarkan leluasa. Hal demikian ini untuk merangsang agar hukum-hukum tersebut bisa lebih berkembang dinamis yang pada gilirannya juga akan memberikan sumbangan yang dinamis pula bagi perkembangan hukum Indonesia secara keseluruhan.

Abdurrahman Wahid mengkhawatirkan kalau Islam ditempatkan sebagai satu-satunya alternatif justru akan kehilangan relevansinya. Kalau Islam di Indonesia mau benar, maka lihatlah Islam hanya sebagai pemberi warna, tempatkanlah Islam sebagai jantung dan urat nadi dari segala persoalan, tidak lebih dari itu. Jika Islam difungsikan sebagai kebenaran tunggal, sedang yang lain harus mengalah, maka Islam hanya akan menjadi agama eksklusif. Kita sebagai bangsa sudah terlanjur pluralistik. Menurutnya, Islam dapat berfungsi sepenuhnya dalam kehidupan masyarakat tertentu, melalui pengembangan nilai dasarnya sebagai etika masyarakat. Fungsi ini bukanlah bentuk tertentu negara, tetapi sebuah sistem etika sosial yang dimaksudkan untuk membimbing masyarakat dan negara sehingga sesuai dengan martabat manusia. Terdapat banyak hukum agama yang tidak murni berlaku dalam bentuk petunjuk moral yang dilaksanakan umat dengan penuh kesadaran. Kebebasan agama tidak akan hilang dengan fungsinya sebagai sistem etika sosial. 
UNISIA, Vol. XXX No. 65 September 2007

\section{Kesimpulan}

Dari uraian yang sudah dipaparkan di atas, dapat disimpulkan bahwa formalisasi dan pemberlakuan syariat Islam dalam konteks bangsa Indonesia yang pluralistik memang tidak semudah pengucapannya, sebab pada tataran konsep, proses, dan konsekuensi hukum maupun politiknya masih harus dicarikan titik persamaan pandang terlebih dahulu. Secara konsepsional, ediom tentang "syariat Islam" masih terus diperdebatkan; apakah mengikuti pola pandang yang inklusif, eksklusif, atau mungkin yang sekuler. Demikian juga proses dan konsekuensi dari formalisasi syariat Islam-pun mengalami pasang dan surut dalam pembaharuan sistem ketatanegaraan Indonesia.

Oleh karena itu, pembahasannya tidak sekadar mencari legitimasi legal formal, namun harus diarahkan pada seberapa banyak hukum Islam mampu menyumbangkan nilai-nilainya dalam rangka kemajuan, keteraturan, ketentraman dan kesejahteraan dalam kehidupan berbangsa dan bernegara.

\section{Daftar Pustaka}

Abdul Ghofur,2002, Demokratisasi dan Prospek Hukum Islam di Indonesia, Yogyakarta: Walisongo Press dan Pustaka Pelajar.

Abdul Halim,2000, Peradilan Agama dalam Politik Hukum Indonesia, Dari otoriter Konservatif menuju Konfigurasi Demokratis-Responsif, Jakarta: Rajawali Pers.

A. Qodri Azizy,2002, Eklektisisme Hukum Nasional, Komppetisi Antara Hukum Islam dan Hukum Umum, Yogyakarta: Gama Media.
Ahmad Sukarja,1995, Dialektika hukum Islam dan Kekuasaan (Sejarah dan Perkembangannya), makalah disampaikan pada Simposium dan Perbincangan Nasional tentang Hukum Islam dalam Wacana Kebangsaan dan Kenegaraan, IAIN Sunan Kalijaga, Yogyakarta.

Amrullah Ahmad dkk.1996, Dimensi Hukum Islam Dalam Sistem Hukum Nasional, Jakarta:Gema Insani Press.

Arief Afandi (ed.) 1996, Islam Demokrasi Atas Bawah Polemik Strategi Perjuangan Umat Model Gus Dur dan Amin Rais, Yogyakarta:Pustaka Pelajar.

Bahtiar Effendy, 2001,Teologi Baru Politik Islam, Pertautan Agama, Negara, dan Demokrasi, Yogyakarta:Galang Press.

Fachry Ali dan Bahtiar Effendy, 1996, dalam Merambah Jalan Baru Islam, Bandung:Mizan.

Greg Barton, 1999, Gagasan Islam Liberal Indonesia: Pemikiran NeoModernisme Nurcholis Madjid, Djohan Effendy, Ahmad Wahib dan Abdurrahman Wahid,Jakarta: Paramadina, Pustaka Antara, Yayasan Adikarya dan The Ford Foundation.

Haedar Nashir,2006, Gerakan Islam Syariat, Reproduksi Salafiah Ideologis di Indonesia, Disertasi, Yogyakarta: Pascasarjana Universitas Gadjah Mada.

Jazim Hamidi dkk.2003, Laporan Hasil Akhir Penelitian Kompetitif dengan judul Rekayasa Model Pembuatan Per- 
Pelembagaan Hukum Islam Untuk Masa Depan Bangsa Indonesia..., Ni'matul Huda

aturan Daerah Berbasis Syariat Islam, Tasikmalaya:Institut Agama Islam Cipasung .

K.H. M.A. Sahal Mahfudh, "Peran Hukum Islam dalam Menciptakan Masyarakat Madani Indonesia", Makalah disampaikan dalam diskusi di Pascasarjana IAIN Walisongo, Semarang, 27 September 2001.

Masdar F. Mas'udi,1993, Agama Keadilan: Risalah Zakat (Pajak) dalam Islam, Jakarta: Pustaka Firdaus.

Moh. Mahfud MD.1999, Pergulatan Politik dan Hukum di Indonesia, Yogyakarta: Gama Media.

, Politik Hukum Dalam Perda Berbasis Syariah, Makalah Stadium General untuk Pembukaan Kuliah Pascasarjana IImu Hukum pada Program Pascasarjana Fakultas Hukum Universitas Islam Indonesia (UII) Yogyakarta, Sabtu, 11 November 2006.

M. Syafei Anwar,1995, Pemikiran dan Aksi Islam Indonesia: Sebuah Kajian Tentang Cendekiawan Muslim Orde Baru, Jakarta:Paramadina.

Murjani, 2002, Perkembangan Legislasi Hukum Islam Dalam Pembentukan Sistem Hukum Nasional: Tinjauan Yuridis dan Politis, Tesis, Yogyakarta:Program Magister Ilmu Hukum Universitas Islam Indonesia.

Ni'matul Huda,2005, Negara Hukum, Demokrasi \& Judicial Review, Yogyakarta:UII Press.
R. William Liddle,1988, Politics and Cultural in Indonesia, Ann Arbor: Center for Political Studies Institute for Social Research The University of Michigan Center.

Sayuti Thalib, 1987, Politik Hukum Baru, Bandung: Bina Cipta.

Subekti,1982, Law in Indonesia, Yayasan Proklamasi Jakarta: C S I S.

Taufik Adnan Amal dan Samsu Rizal Panggabean,2004, Politik Syariat Islam Dari Indonesia Hingga Nigeria, Jakarta: Pustaka Alfabet.

Zainal Abidin Amir,2003, Peta Islam Politik Pasca Soeharto.Jakarta: LP3ES.

Prisma, Volume 3, Maret 1991.

Gatra, No. 26 Tahun VII, 19 Mei 2001.

Kompas, 17 Mei 2000.

Sinar Harapan, 8 November 2002.

Suara Pembaruan, 8 November 2002.

Pikiran Rakyat, 8 November 2002.

Gatra, Edisi Khusus, No. 02-03 Tahun X, 6 Desember 2003

Jurnal IImu-ilmu Sosial UNISIA, No. 48/XXVI/ II/2003.

Jurnal MAHKAMAH, Vol. 12, No. 2, Oktober 2001. 